\title{
PELEPASAN INFORMASI REKAM MEDIS KEPADA PIHAK KETIGA DI RUMAH SAKIT MITRA MEDIKA
}

\author{
${ }^{1 .}$ Suheri Parulian Gultom; ${ }^{2 .}$ Sisca Anggraini \\ 1. Dosen APIKES Imelda, Jalan Bilal Nomor 52 Medan; ${ }^{2 .}$ Alumni APIKES Imelda \\ E-mail: ${ }^{1 .}$ suheriparuliangultom@gmail.com
}

\begin{abstract}
ABSTRAK
Sarana pelayanan kesehatan bertanggung jawab untuk melindungi informasi kesehatan yang terdapat didalam rekam medis terhadap kemungkinan hilang, rusak, pemalsuan dan akses yang tidak sah. Secara keseluruhan, keamanan (security), privasi (privacy), kerahasian (confidentiality) dankeselamatan (safety) adalah perangkat yang membentengi informasi dalam rekam medis. Tujuan penelitian ini adalah untuk mengetahui gambaran pelepasan informasi rekam medis di Rumah Sakit Mitra Medika Medan. Jenis penelitian berupa deskriptif yaitu metode penelitian yang dilakukan dengan tujuan untuk membuat gambaran tentang suatu keadaan secara objektif. Populasi penelitian ini adalah pelepasan informasi rekam medis dalam menjamin kepada pihak ketiga, sampel penelitian 20 permintaan visum. Teknik pengambilan sampel yaitu dengan cara teknik nonprobability. Dari hasil penelitian diketahui bahwa Data permintaan visum kepolisian/pengadilan pada bulan Oktober 2017 - Januari 2018 di Rumah Sakit Mitra Medika Medan berjumlah 20 permintaan dengan persentase (25\%). Sedangkan penggunaan informasi untuk penelitian sebanyak 10 permintaan dengan persentase (50\%). Adapun pihak-pihak yang terlibat dalam proses pelepasan informasi medis pasien Rumah Sakit Mitra Medika Medan adalah Diklat, Sub Bag Rekam Medis, Dokter/Tenaga Medis dan petugas ruangan.Sebaiknya diadakan sosialisasi tentang prosedur tetap mengenai pelepasan informasi medis pasien kepada petugas rekam medis ataupun pihak yang terlibat dalam pelepasan informasi medis pasien.
\end{abstract}

Kata Kunci: Pelepasan Informasi RM, Pihak Ketiga.

\section{PENDAHULUAN}

Pembangunan kesehatan yang mengarah untuk mewujudkan derajat kesehatan yang optimal berdampak pada perkembangan informasi kesehatan yang juga harus semakin meningkat. Rekam Medis sebagai bagian dari pelayanan umum di sebuah Rumah Sakit yang salah satu pelayanannya adalah menyelenggarakan pelepasan informasi isi Rekam Medis pasien yang sesuai dengan standar yakni berisi informasi lengkap perihal proses pelayanan kesehatan dimasa lalu, masa kini, dan perkiraan dimasa mendatang.

$$
\text { Berdasarkan PerMenKes RI }
$$

No.269/MENKES/ PER/ III/ 2008 pasal 1 menyatakan bahwa "Rekam Medis adalah berkas yang berisikan catatan dan dokumen tentang identitas pasien, pemeriksaan, pengobatan, tindakan, dan pelayanan lain yang telah diberikan kepada pasien". Rekam Medis memiliki peran dan fungsi yang sangat penting, yaitu sebagai dasar pemeliharaan kesehatan dan pengobatan pasien, bahan pembuktian dalam perkara hukum, bahan untuk keperluan penelitian dan pendidikan, dasar pembayaran biaya pelayanan kesehatan dan terakhir sebagai bahan untuk membuat statistik kesehatan (Hatta, 2012).

Karena informasi medis bersifat rahasia, maka dalam pelepasan informasi kepada pihak lain (secondary release) sarana kesehatan bertanggung jawab untuk melindungi informasi kesehatan yang terdapat didalam Rekam Medis terhadap kemungkinan hilang, rusak, pemalsuan dan akses yang tidak sah. Rekam Medis hanya dapat dikeluarkan berdasarkan otoritas 
Rumah Sakit yang berwenang, dan kerahasiaan isinya dikeluarkan berdasarkan izin dari pasien yang bersangkutan, sehingga informasi yang terdapat didalamnya dapat dipertanggung jawabkan. Secara keseluruhan, keamanan, privasi, kerahasiaan dan keselamatan adalah perangkat yang membentengi informasi dalam Rekam Medis. Rumah Sakit selaku pemilik informasi dalam Rekam Medis, prosedur pelepasan informasi Rekam Medis juga harus disertai dengan izin tertulis dari pasien begitu pula dengan pemaparan isi Rekam Medis, haruslah dokter yang merawat pasien tersebut. Ini sejalan dengan PerMenKes No.269/MENKES/PER/III/2008, pasal 11 ayat (1). "Penjelasan tentang isi Rekam Medis hanya boleh dilakukan oleh dokter atau dokter gigi yang merawat pasien dengan izin tertulis pasien atau berdasarkan peraturan perundang-undangan". (H. Triyo, 2012).

Berdasarkan survey yang dilakukan pada bulan Juni di Rumah Sakit Mitra medika Medan, Pelepasan Informasi Rekam Medis Kepada Pihak Ketiga adalah tentang ada nya pelepasan informasi kepada pihak ketiga yaitu kepada bagian kepolisian baikpun visum dalam bagian kelengkapan kepada visum.di dominasi oleh penggunaan informasi medis dengan keperluan visum sebanyak 20 permintaan.

Dari permasalahan tersebut penulis tertarik untuk meneliti dengan mengambil judul "Pelepasan Informasi Rekam Medis Kepada Pihak Ketiga Di Rumah Sakit Mitra Medika Medan”.

\section{Rumusan Masalah}

Berdasarkan latar belakang masalah tersebut maka perumusan masalah dalam penelitian ini adalah "Apakah pelepasan informasi rekam medis RS Mitra Medika Medan telah menjamin aspek hukum kerahasian rekam medis pasien"?

\section{Tujuan Penelitian}

Untuk mengetahui gambaran pelepasan informasi kepada pihak ketiga di Rumah Sakit Sakit Mitra Medika Medan.

\section{Manfaat Penelitian}

1. Bagi Instansi Rumah Sakit

Hasil penelitian ini diharapkan dapat memberikan manfaat untuk pihak yang dijadikan objek penelitian yaitu Rumah Sakit Mitra Medika Medan dan menjadi bahan masukkan serta pertimbangan bagi pihak Rumah Sakit dalam melepas informasi kepada pihak ketiga.

2. Bagi Akademik.

Penelitian ini, peneliti dapat ikut serta dalam menambah wawasan dan referensi perpustakaan Yayasan Imelda Medan dan sebagai acuan bagi penelitian berikutnya.

3. Bagi Peneliti

Penelitian ini diharapkan dapat meningkatkan wawasan dan pengetahuan bagi peneliti atau pun mahasiswa Rekam Medis dalam upaya mengetahui bagaimana pelepasan informasi Kepada Pihak Ketiga dilakukan serta sebagai sarana untuk menerapkan ilmu yang diperoleh selama kuliah dengan yang ada di lapangan khususnya dalam pelepasan informasi kepada pihak ketiga.

\section{METODE}

\section{Jenis Penelitian}

Penelitian ini adalah penelitian deskriptif yang bertujuan untuk mengetahui keterkaitan terhadap pelepasan informasi berkas rekam medis terhadap rekam medis di sebuah rumah sakit, (Notoatmodjo,2012).

\section{Waktu Penelitian}

Penelitian dilaksanakan pada bulan Oktober 2017-Januari 2018.

\section{Tempat Penelitian}

Tempat ini dilaksanakan di Rumah Sakit Mitra Medika Medan, khasusnya di bagian pelepasan informasi rekam medis kepada pihak ketiga di Rumah Sakit Mitra Medika Medan adalah salah satu Rumah Sakit milik organisasi social kota Medan yang bertipe $\mathrm{C}$ dan beralamat di JL.K.L.Yos Sudarso Km. 7,5 Tanjung Mulia alas an peneliti mengambil tempat penelitian ini adalah penelitian sebelumnya telah 
melakukan wawancara pada petugas rekam medis dan hasil mengatakan bahwa ada banyak kasus dalam pelepasan informasi rekam medis kepada pihak ketiga, selain itu, lokasi penelitian dapat dijangkau oleh peneliti.

\section{Populasi}

Populasi merupakan keseluruhan sumber data yang diperlukan dalam suatu penelitiian, Suryono (2008). Populasi dalam penelitian ini adalah pelepasan informasi rekam medis kepada pihak ke-3 di Rumah Sakit Mitra Medika Medan berjumlah 4 (empat) orang.

\section{Sampel}

Sebagian yang diambil dari keseluruhan objek yang diteliti dan dianggap mewakili seluruh populasi. (Notoatmodjo, 2005). Dalam penelitian ini sampel

yang digunakan adalah sebagian pelepasan informasi rekam medis pihak ke -3 pada bulan Oktober 2017- Januari 2018. Sehingga dalam penelitian penulis mengambil sampel dengan menggunakan teknik nonprobability. sampel penilitian berjumlah 4 (empat) orang.

\section{Teknik Sampling}

Teknik sampling yang digunakan dalam penelitian ini adalah teknik total sampling yaitu dimana semua populasi digunakan sebagai sampel yaitu petugas di RumahSakitMitra medika di bagian pelepasan informasi kepada pihak ketiga berjumlah 4 (empat) orang.

\section{Variabel Peneliti}

Variabel adalah sesuatu yang digunakan sebagai ciri, sifat, atau ukuran yang dimiliki atau didapatkan oleh satuan peneliti tentang sesuatu konsep pengertian tertentu . (notoatmodjo, 2010). Variabel dalam penelitian ini adalah :

1. Aspek Hukum Kesehatan

a. Alur permintaan visum et repertum

b. Prosedur tetap tentang pembuatan visum et repertum

c. Penggagendaan visum et repertum

2. Protap pelepasan informasi medis untuk keperluan visum et repertum

3. Pelepasan informasi medis untuk keperluan visum et repertum

\section{Defenisi Operasional}

Untuk membatasi ruang lingkup atau pengertian variabel-variabel yang diteliti/diamati, perlu sesekali variabel-variabel tersebut diberi batasan atau defenisi operasional (Notoatmodjo, 2005).

\begin{tabular}{|c|c|c|c|}
\hline No & Variabel & Definisi & Operasional \\
\hline \multirow[t]{3}{*}{1} & $\begin{array}{l}\text { Aspek Hukum Kesehatan } \\
\text { Alur permintaan visum et repertum }\end{array}$ & $\begin{array}{l}\text { Alur pelaksanaan permintaan } \\
\text { visum et repertum }\end{array}$ & $\begin{array}{l}\text { di RS Mitra Medika } \\
\text { Medan }\end{array}$ \\
\hline & $\begin{array}{l}\text { b. Prosedur tetap pembuatan visum } \\
\text { et repertum }\end{array}$ & $\begin{array}{l}\text { Tahap-tahap pelaksanaan } \\
\text { pelaksanaan pembuatan visum et } \\
\text { repertum yang sudah ditetapkan } \\
\text { oleh rumah sakit. }\end{array}$ & $\begin{array}{l}\text { di RS Mitra Medika } \\
\text { Medan }\end{array}$ \\
\hline & c. Pengagendaan visum et repertum & $\begin{array}{l}\text { Cara pencatatan surat permintaan } \\
\text { visum et repertum kedalam buku } \\
\text { agenda rumah sakit. }\end{array}$ & $\begin{array}{l}\text { di RS Mitra Medika } \\
\text { Medan }\end{array}$ \\
\hline 2 & $\begin{array}{l}\text { Protap pelepasan informasi medis } \\
\text { untuk keperluan visumet repertum }\end{array}$ & $\begin{array}{l}\text { Tahap-tahap pelaksanaan } \\
\text { pelepasan informasi medis untuk } \\
\text { keperluan visum et repertum yang } \\
\text { sudah ditetapkan oleh rumah sakit. }\end{array}$ & $\begin{array}{l}\text { di RS Mitra Medika } \\
\text { Medan }\end{array}$ \\
\hline
\end{tabular}




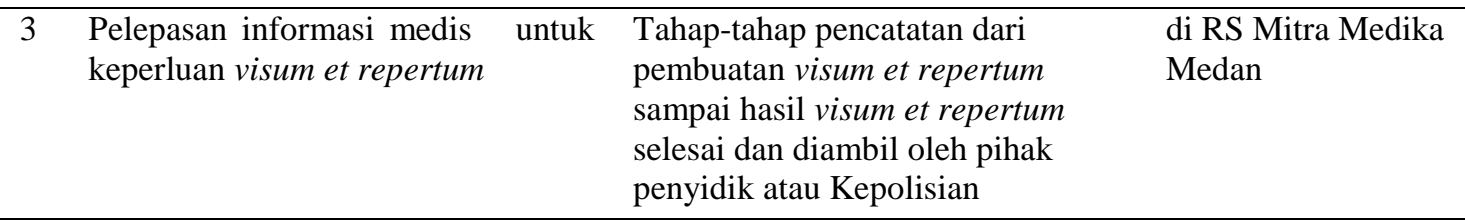

\section{Instrumen Penelitian}

Instrumen penelitian yang digunakan dalam penelitian adalah:
a. Pedoman wawancara
b. Pedoman observasi

\section{Teknik Pengumpulan Data}

\section{Observasi}

Observasi atau pengamatan adalah suatu prosedur yang berencana, yang antara lain meliputi melihat dan mencatat jumlah dan taraf aktivitas tertentu yang ada hubungannya dengan masalah yang diteliti (notoatmodjo 2010). Proses dan syarat pelepasan informasi pasien akan menjadi objek observasi.

2. Wawancara

Wawancara adalah suatu metode yang digunakan untuk mengumpulkan data, dimana peneliti mendapat keterangan atau perincian secara lisan dari seseorang sasaran peneliti atau bercakap-cakap secara face to face (Notoatmodjo, 2010).

3. Teknik Analisa Data

Analisa data yang digunakan adalah analisis univariat yang dilakukan terhadap tiap variabel dari hasil penelitian. Pada umumnya analisis ini hanya menghasilkan distribusi dan persentase dari tiap variabel. Cara penyajian data dalam penelitian ini adalah dengan penyajian data dalam bentuk tabular dan tekstular.

\section{HASIL}

Setelah Melakukan Penelitian yang dilakukan penulis mengenai " pelepasan informasi rekam medis di Rumah Sakit Mitra Medika Medan". Dengan jumlah responden sebanyak 4 orang. Maka hasil yang diperoleh adalah sebagai berikut:

\section{Karakteristik responden}

Table 1. Distribusi Karakteristik responden Pendidikan Pelepasan Informasi Rekam Medis Kepada Pihak Ketiga di Rumah Sakit Mitra Medika Medan

\begin{tabular}{cclc}
\hline No & Pendidikan & Frekuensi & \% \\
\hline 1 & SMA & 4 & 100 \\
\hline 2 & D3 & 0 & \\
\hline Total & 4 & 100 \\
\hline
\end{tabular}

Dari tabel di atas dapat dilihat bahwa responden yang berpendidikan SMA sebanyak 4 orang (100\%) dan yang berpendidikan D3 (0\%)

Tabel 2. Distribusi Responden Yang Mengikuti Pelatihan Pelepasan Informasi RekamMedis Kepada Pihak Ketiga Di Rumah Sakit Mitra Medika Medan

\begin{tabular}{clll}
\hline No & Penelitian & Frekuensi & \multicolumn{1}{c}{$\%$} \\
\hline 1 & Pernah & 2 & 50 \\
\hline 2 & Tidak pernah & 2 & 50 \\
\hline Total & 4 & 100 \\
\hline
\end{tabular}

Dari tabel di atas dapat dilihat bahwa bahwa responden yang pernah mengikuti pelatihan ada sebanyak 2 orang $(50 \%)$ dan yang tidak pernah mengikuti pelatihan ada sebanyak 2 orang (50\%).

Tabel 3. Distribusi Responden Yang Mendapati Kejadian Pelepasan Informasi Rekam Medis Kepada Pihak Ketiga Di Rumah Sakit Mitra Medika Medan

\begin{tabular}{cccc}
\hline No & $\begin{array}{c}\text { Jumlah kejadian } \\
\text { pelepasan } \\
\text { informasi }\end{array}$ & Frekuensi & $\%$ \\
\hline 1 & 2 kali & 1 & 25 \\
\hline 2 & $3 \mathrm{kali}$ & 2 & 50 \\
\hline 3 & $4 \mathrm{kali}$ & 1 & 25 \\
\hline Total & 4 & 100
\end{tabular}

Dari tabel di atas dapat di lihat bahwa responden yang mendapati kejadian pelepasan informasi rekam medis kepada pihak ketiga 2 kali dalam satu bulan adalah 1 orang (25\%), petugas yang mendapati kejadian pelepasan informasi 3 kali dalam satu bulan adalah sebanyak 2 orang (50\%), 
dan petugas yang mendapati kejadian pelepasan informasi 4 kali dalam satu bulan adalah sebanyak 1 orang $(25 \%)$. Kesimpulan dari tabel di atas didapat bbahwa rata-rata kejadian pelepasan informasi rekam medis oleh petugas adalah sebanyak 3 kali. Di Rumah Sakit Mitra Medika bahwa dari 3000 pelepasan informasi rekam medis dalam bulan jumlah rata-rata kejadian pelepasan informasi rekam medis kepada pihak ketiga adalah sebanyak 3 kali maka, persentase kejadian pelepasan informasi rekam medis adalah sebagai berikut:

$$
\begin{aligned}
& =\frac{\text { jumlah kejadian pelepasan informasi }}{\text { jumlah pelepasan rekam medis dalam satubu }} \\
& =\frac{3}{300} \times 100 \% \\
& =0,1 \%
\end{aligned}
$$

Dari hasil perhitungan diatas bahwa kejadian pelepasan informasi rekam medis kepada pihak ketiga dalam satu bulan adalah $0,1 \%$

\section{PEMBAHASAN}

Setelah dilakukan penelitian mengenai pelepasan informasi rekam medis kepada pihak ketiga di Rumah Sakit Mitra Medika Medan dengan 4 (empat) responden, maka dapat disimpulkan bahwaseluruh petugas rekam medis berpendidikan SMA.Petugas pelepasan informasi kepada pihak ketiga sebanyak 2 orang $(50 \%)$ dan yang tidak pernah mengikuti pelatihan ada sebanyak 2 orang $(50 \%)$. Dan jumlah rata-rata kejadian pelepasan informasi rekam medis kepada pihak ketiga dalam satu sebulan oleh petugas pelepasan informasi rekam medis kepada pihak ketiga adalah 3 kali, dengan kejadiannya $0,1 \%$.

Dari table diatas dapat dilihat bahwa responden yang berpendidikan SMA sebanyak 4 orang (100\%) dan yang berpendidikan D3 (0\%). Dari tabel diatas dapat dilihat bahwa bahwa responden yang pernah mengikuti pelatihan ada sebanyak 2 orang (50\%) dan yang tidak pernah mengikuti pelatihan ada sebanyak 2 orang (50\%).dapat di lihat bahwa responden yang mendapati kejadian pelepasan informasi rekam medis kepada pihak ketiga 2 kali dalam satu bulan adalah 1 orang (25\%), petugas yang mendapati kejadian pelepasan informasi 3 kali dalam satu bulan adalah sebanyak 2 orang (50\%), dan petugas yang mendapati kejadian pelepasan informasi 4 kali dalam satu bulan adalah sebanyak 1 orang $(25 \%)$.

Kesimpulan dari tabel di atas didapat bahwa rata-rata kejadian pelepasan informasi rekam medis oleh petugas adalah sebanyak 3 kali. Di Rumah Sakit Mitra Medika bahwa dari 3000 pelepasan informasi rekam medis dalam bulan jumlah rata-rata kejadian pelepasan informasi rekam medis kepada pihak ketiga adalah sebanyak 3 kali.

\section{KESIMPULAN}

Dari hasil penelitian yang telah dilakukan dapat disimpulkan sebagai berikut : Penggunaan informasi medis di Rumah Sakit Mitra Medika Medan, di dominasi oleh penggunaan informasi medis dengan keperluan visum sebanyak 20 permintaan dengan persentase (25\%). Sedangkan penggunaan informasi untuk keperluan penelitian sebanyak 10 permintaan (50\%).

Adapun pihak-pihak yang terlibat dalam proses pelepasan informasi medis pasien Rumah Sakit Mitra Medika Medan adalah Diklat, Sub Bag Rekam Medis, Dokter/Tenaga Medis dan petugas ruangan.

\section{SARAN} Medan

Bagi Rumah Sakit Mitra Medika

1. Dalam menjaga kerahasiaan dan keamanan informasi pasien di Rumah Sakit Mitra Medika Medan, sebaiknya didalam sub bagian Rekam Medis terdapat buku pencatatan pengguna informasi rekam medis yang bertujuan untuk mendokumentasikan pengguna informasi rekam medis yang bertujuan untuk mendokumentasikan pengguna informasi medis serta sebagai bentuk bukti apabila terjadi tuntutan kelak.

2. Sebaiknya diadakan sosialisasi tentang prosedur tetap mengenai pelepasan informasi medis pasien kepada petugas rekam medis ataupun pihak yang 
terlibat dalam pelepasan informasi medis pasien.

\section{DAFTAR PUSTAKA}

Depkes RI. (1997). Petunjuk Teknis Penyelenggaraan Rekam Medis Rumah Sakit. Jakarta: Dirjen Yanmed.

Ery, Rustiyanto. (2009). Etika Profesi Perekam Medis dan Informasi Kesehatan. Yogyakarta: Graha Ilmu.

J, Gusnandi. (2005). Rahasia Medis. Jakarta: Graha Ilmu.

Menteri Kesehatan Republik Indonesia. (2008). Peraturan Nomor: 269/MENKES/PER/III/2008, tentang Rekam Medis. Jakarta: Departemen Kesehatan RI.

Notoatmodjo, S. (2010). Metodologi Penelitian Kesehatan Edisi Revisi. Jakarta: Rineka Cipta.

Notoatmodjo, Soekidjo. (2005). Metodologi Penelitian Kesehatan. Jakarta: Rineka Cipta.
Presiden Republik Indonesia. (1996). Peraturan Pemerintah No.10 Tahun 1996 tentang Wajib Simpan Rahasia Kedokteran. Jakarta.

Presiden Republik Indonesia. (2004). Undang - undang Republik Indonesia Nomor 29 Tahun 2004 tentang Praktik Kedokteran. Jakarta.

Presiden Republik Indonesia. (2009). Undang- undang Republik Indonesia Nomor 36 Tahun 2009 tentang kesehatan. Jakarta.

Rustiyanto, Ery. (2009). Etika Profesi Perekam Medis dan Informasi Kesehatan. Yogyakarta: Graha Ilmu.

Sunny Ummul Firdaus. (2008). Rekam Medis dalam Sorotan Hukum dan Etika. Surakarta.

World Health Organization. (2006). Medical Records Manual A Guide For Developing Countries. Geneva: WHO. 